\title{
Driving and Fostering Strategic University and Industry Collaboration: Perspective from the Food Manufacturers
}

\author{
Ng Kim-Soon, Juwita Anwar, Wahid Razzaly and Abd Rahman Ahmad \\ Universiti Tun Hussein Onn Malaysia, Batu Pahat, Johor, Malaysia
}

Correspondence should be addressed to: Ng Kim-Soon; ksng@uthm.edu.my

Received date: 21 March 2014; Accepted date: 14 July 2014; Published date: 7 October 2015

Academic Editor: Rym Hchich

Copyright (C) 2015. Ng Kim-Soon, Juwita Anwar, Wahid Razzaly and Abd Rahman Ahmad. Distributed under Creative Commons CC-BY 4.0

\begin{abstract}
Universities are fostering links and facilitating technology transfer with industries. Industries are transforming rapidly to sustain and ensure businesses prosper well. These have created a dynamic approach by stakeholders towards university-industry collaboration (UIC). However, there is a lack of studies which focus on how the process of formation of the partnerships are developed and coordinated effectively. This case study examines the drivers of change in fostering collaboration of a Public University, an anchor institution located in a town with its surrounding food processing companies. Data were collected from 5 Chief Executive Officers of the food processing companies, as they are among the key decision makers who are able to influence the future direction of UIC of food industry. Face-to-face interviews were used to collect the views of the industry foresight into the year 2025. The rate of technology adoption and policies are the two key drivers of change driving future UIC between UTHM, an anchor institution in the Town with its surrounding food processing companies. This paper has made recommendation for future of the University and Food Industry collaborative linkages.
\end{abstract}

Keywords: University-Industry Collaboration, University, Food Industry, Drivers of Change, Foresight.

\section{Introduction}

Universities were considered as the ivory towers which were less concerned about the world outside as they were more concerned about the intellectual pursuits decades ago (Ismail \& Abas, 2010). However, the social and egalitarian awakening has caused the university to gradually move away from this traditional concept and to display a stronger commitment to the welfare of the society. Universities are fostering links and facilitating technology transfer with industries. Malaysia is heading toward a new

Cite this Article as: Ng Kim-Soon, Juwita Anwar, Wahid Razzaly and Abd Rahman Ahmad (2015)," Driving and Fostering Strategic University and Industry Collaboration: Perspective from the Food Manufacturers", Journal of Southeast Asian Research, Vol. 2015 (2015), Article ID 725644, DOI: 10.5171/2015.725644 
era of knowledge based economy. Knowledge has become the main driver of Malaysia's economy. Numerous researchers have concluded that in order for a country to success in this knowledge based economy, the industry should know how to acquire, use and leverage knowledge effectively (Sohail, 2009).

There are a total of 44 food processing companies in Batu Pahat township. UTHM with a students' population of more than 16,000 people and work force of 2,000 people is considered an anchor institution in this town. It is important to target UTHM and the food companies for this research as they are critical players in the region to build linkages between university, industry and commerce in order to contribute to the economic development of the region. The performance of UIC could be particularly affected by geographical proximity as this facilitates frequent direct contacts between the academicians and the industrial partners. Dodd and Patra (2002) suggested that networking processes are particularly beneficial when the network partners are geographically close to each other. Firms are more likely to collaborate with university near to where it is located although the prestige of university mitigates the effect of geographical proximity (Laursen et al., 2001; Piva \& Rossi-Lamastra, 2013). Theory of anchor institutions (Agrawal and Cockburn, 2003) claimed that anchor institutions e.g. universities and large firms have important economic impacts due to their employment, revenue-garnering and spending patterns thus benefiting the regional economy. Thus, it is very significant to determine what drives UIC success of UTHM and the anchor institutions to benefit Batu Pahat economic and social development.

Through UIC, the interactions between university and industry can aid in knowledge transfer and stimulate the generation of new knowledge. However, there are some barriers and challenges in understanding the collaboration between university and industry. In this case, understanding key drivers can help to increase the chances of success in UIC. The key drivers can be identified based on the STEEPV analysis which stands for Social, Technological, Economic, Environmental, Political and Values. Drivers act as the forces of change. STEEPV is used to create an overview of the current situation and brought to a further investigation (Pillkahn, 2008). In this concern, the purpose of this study is to determine the key drivers of change in UIC between UTHM and the food processing industry in Batu Pahat, a town located in the state of Johor, Malaysia using foresight approach.

\section{Literature Review}

The roles of university and industry in innovation have evolved from the traditional model to the new model. University and industry continue to produce their traditional outputs since decades ago. Due to the new demands for sustenance and survival in this competitive business environment, university and industry have undergone real-time relationships and direct technology transfer. They are creating new opportunities such as new ventures and new knowledge (Dasher, 2004).

Literatures (2007-2012) revealed that knowledge transfer and strategies of collaboration and characteristics of collaboration are the most popular issues being discussed. Other issues being discussed among researchers include industry relevance, academic rigidity and the issue related to internship. In this study, it is related to the category of the level of linkages between industry and the university (Gertner, Roberts \& Charles 2011; Junaini, Fadzir, Sidi, Khiri \& Othman, 2011; Baysal, 2007; Kondo, 2011; Hamidah, Maziah, Ayesha, Subahan, \& Rahayah, 2012 ). Among the modes of theorizing imbedded in this field of study include - alliance process perspectives (Inkpen \& Curall, 2004), dynamics of cooperation perspective 
(Larson, 1992), which focus on governance of inter-organizational relationships (Inkpen \& Curall, 2004) and learning and knowledge transfer in inter-organizational relationship (Vlaar, Bosch, \& Volberda, 2007).

Reviews and works on UIC in Malaysia and other countries indicate the criticalness of forging close collaborations is a very active research area and it is attracting lots of attentions (Pecas \& Henriques, 2006; Hermans \& Castiaux, 2007; Esham, 2008; Kondo, 2011; Bjerregaard, 2009; Gertner et al., 2011). Strategic Enhancement Plan for University and Community Collaboration stated that universities today are not confined only to the generation of new knowledge, but also to encompass the creation of applicable and economically useful knowledge for the well beings of society, as universities are supposed to be the nation's economic and intellectual engines (Ismail \& Abas, 2010). Most of the universities in Malaysia have initiative to set up a liaison office to further strengthen its strategic alliance with the industry. Liaison office in university is similar to the marketing department of a company (Fassin, 2000).

Collaboration between university and industry can yield synergy. It begins with university providing professional education which results in producing competent workforce that is needed by the industry. Besides producing competent human capital, university does industry-based research which will yield more customized study programmes. On the other hand, the industry can provide funds and helps to enhance and develop curriculum by certifying the study program (Junaini et al., 2008). As a whole, this synergy model will yield mutual benefits for both university and industry.

The major events in the history of food industry had conveyed an important message to every one of us in the food chain. It is telling us that technology advancement, creativity, innovation, research and development (R\&D) have played a major role in the evolution of food industry. From the perspective of industry, the increase of market competitiveness has worsened the condition for the players in the industry to get a piece of the pie. For this, collaboration with university is an alternative for food industry to access to the sources of funds, skills, expertise, talents and facilities for R\&D. Vauterin (2012) reviewed that these sources are crucial in increasing their competitive advantages. A better understanding and adequate managing of boundary roles between university and industry will help to decrease the perceived market demand uncertainty surrounding university and industry. He further suggested that in-depth research is needed for the development of a holistic understanding of how partnering for university and industry is experienced.

The drivers of change are the key factors that support the important trends and issues. The drivers will be identified using the STEEPV analysis that determine the uncertain terms of possible development and implication. The drivers are the trends, technologies and issues that act as driving forces for future changes. Table 1 tabulates the categories of STEEPV analysis of UIC from the works of previous researches.

Table 1: A review of STEEPV analysis for UIC

\begin{tabular}{|c|c|c|}
\hline Categories & Factors & Key drivers \\
\hline Social & $\begin{array}{l}\text { Gen Y becomes 75\% of the workforce in } 2025 \text { (Business } \\
\text { and Professional Women's Foundation, 2011) } \\
\text { Due to time scarcity, meal fragmentation, speed shopping } \\
\text { and the erosion of cooking skills, consumers prefer to } \\
\text { consume convenience food (Agriculture and Agri-Food }\end{array}$ & $\begin{array}{l}\text { Characteristic of } \\
\text { workforce } \\
\text { Convenience food } \\
\text { trend } \\
\text { Health conscious }\end{array}$ \\
\hline
\end{tabular}




\begin{tabular}{|c|c|c|}
\hline & $\begin{array}{l}\text { Canada, 2010). } \\
\text { Consumers are getting more health conscious and } \\
\text { nutritionally aware (Marshall, Bower, \& Schroder, 2007). } \\
\text { Pallot (2009) mentioned that the social factors below are } \\
\text { the barriers of collabration: } \\
\text { Unbalanced power } \\
\text { Unbalanced expertise } \\
\text { Multi-disciplinary setting } \\
\text { Lack of common } \\
\text { Weak ties } \\
\text { Language barrier } \\
\text { Diversity setting }\end{array}$ & $\begin{array}{l}\text { Unbalanced power } \\
\text { Unbalanced } \\
\text { expertise } \\
\text { Multi-disciplinary } \\
\text { setting } \\
\text { Lack of common } \\
\text { Weak ties } \\
\text { Language barrier } \\
\text { Diversity setting }\end{array}$ \\
\hline Technological & $\begin{array}{l}\text { Paradigm shifts of the industry where they start to realize } \\
\text { that improvement of technology can improve } \\
\text { performance (Cohen, 2004). } \\
\text { Pallot (2009) mentioned that the technological factors } \\
\text { below are the barriers of collabration: } \\
\text { Lack of absorptive capacity } \\
\text { Unbalanced technological usage }\end{array}$ & $\begin{array}{l}\text { Paradigm shift of } \\
\text { technology users } \\
\text { Lack of absorptive } \\
\text { capacity } \\
\text { Unbalanced } \\
\text { technological usage }\end{array}$ \\
\hline Economic & $\begin{array}{l}\text { The need to spread the costs and risks of innovation is } \\
\text { one of the motives of strategic alliance (Mowery, Oxley, \& } \\
\text { Silverman, 1996). } \\
\text { Partnership is one of ways for market development as it } \\
\text { increases the customers' awareness (Foryszewski, 2010). } \\
\text { Many small businesses are looking for partnership as a } \\
\text { way to reduce costs (Holland, 2011). } \\
\text { Partnership is an important part of globalization process } \\
\text { as "Trans-Pacific Partnership" is the prove of it (Bolton, } \\
\text { 2011). }\end{array}$ & $\begin{array}{l}\text { Sharing innovation } \\
\text { costs and risks } \\
\text { Market development } \\
\text { Reduce costs } \\
\text { Globalization }\end{array}$ \\
\hline Environmental & $\begin{array}{l}\text { Pallot (2009) mentioned that the factor of geographical } \\
\text { dispersion is one of the barriers in collaboration. } \\
\text { Partnership is a way of facility sharing. For example in } \\
\text { automobile industry, Renaults utilized Nissan's factory in } \\
\text { Mexico to produce its own model (Kang \& Sakai, 2000). } \\
\text { Arora and Cason (1996); King and Lenox (2000) } \\
\text { suggested two major motives that industry voluntary } \\
\text { participate in green partnership. Firstly, the motive of } \\
\text { industry is to respond to environmental conscious } \\
\text { investors and consumers and develop a "green" } \\
\text { reputation that allows it to take a competitive position in } \\
\text { markets (Arora \& Cason, 1996). Secondly, the motive of } \\
\text { industry is to deal with institutional and regulatory } \\
\text { pressures (King \& Lenox, 2000). }\end{array}$ & $\begin{array}{l}\text { Geographical } \\
\text { dispersion } \\
\text { Facility sharing } \\
\text { To attract green } \\
\text { investors and green } \\
\text { consumers } \\
\text { Regulatory pressure }\end{array}$ \\
\hline Political & $\begin{array}{l}\text { More budgets allocated for UIC, better facilities. } \\
\text { Strict policies discourage industry development, facilities } \\
\text { not up to date as lower budget is allocated for UIC. } \\
\text { Multi-roles played by the academicians (Shariff, 2010). } \\
\text { Pallot (2009) mentioned that the technological factors } \\
\text { below are the barriers of collabration: }\end{array}$ & $\begin{array}{l}\text { S\&T policies } \\
\text { Government policies } \\
\text { Unbalanced } \\
\text { Intellectual Property } \\
\text { Rights (IPR) } \\
\text { approach }\end{array}$ \\
\hline
\end{tabular}




\begin{tabular}{|l|l|l|}
\hline & $\begin{array}{l}\text { Unbalanced Intellectual Property Rights (IPR) approach } \\
\text { Different investment regulations } \\
\text { Lack of common security rules }\end{array}$ & $\begin{array}{l}\text { Different investment } \\
\text { regulations } \\
\text { Lack of common } \\
\text { security rules }\end{array}$ \\
\hline Values & $\begin{array}{l}\text { Uncertain intellectual property rights (IPR) lead to } \\
\text { reduced collaboration (Czarnitzki, Hussinger, \& } \\
\text { Schneider, 2011). } \\
\text { Incentive given to researcher and industry. } \\
\text { Local industries are not risk takers. } \\
\text { Pallot (2009) mentioned that lack of mutual trust is one } \\
\text { of the barriers in collaboration. }\end{array}$ & $\begin{array}{l}\text { Intellectual property } \\
\text { rights (IPR) } \\
\text { Driven by incentive } \\
\text { Risk taking } \\
\text { Lack of mutual trust }\end{array}$ \\
\hline
\end{tabular}

\section{Methodology}

This is a foresight study. The qualitative data for this study were collected and analyzed by using Miles and Huberman (1994) method to determine the key drivers of change in UIC between UTHM and the food processing industry in Batu Pahat. The population of food processing industry in Batu Pahat is 44 Companies. A total of 5 CEOs (Chief Executive Officers) profiled from 5 different representative companies were chosen to be interviewed. These companies are made up collection (secondary data) and Phase 2: main data collection (primary data). The primary data was collected through interviews and questionnaires. The interview questions are in the form of semi-structured format.

The drivers of change are the key factors that support the important trends and issues. These drivers were identified using the STEEPV analysis that determine the uncertain terms of possible development and implication. The drivers are the trends, technologies and issues that act as driving forces for future changes. The second step in scenario building is the analysis of the impact-uncertainty. This step is used to determine the uncertainties in the determination of future of UIC between food processing industry and UTHM. The lists of drivers were placed in accordance to the level of the uncertainty and the level of of big, medium and small companies allowing control of size of companies as a controlled factor in this study because the size of the companies affects UIC performance. The university chosen is UTHM as it is located in Batu Pahat town. This is a new University and has started to provide courses in food technology that makes it suitable to be explored on collaboration between the food processing industry and the university. The data collections of this study relied on the Phase 1: base data

impactful to UIC in year 2025. The drivers with the greatest impact and also most uncertain are the key drivers. The impactuncertainty axis is used to find the most uncertain drivers that might have the higher influence over the future of UIC in food processing industry.

\section{Data Analysis}

This section is on the profile of respondents, the categories of driver determination and reporting on the impact-uncertainty analysis to derive the key drivers of UIC.

\section{Profile of Respondents}

The characteristics of the sampled firms are tabulated in Table 2. The profiled respondents from the industry are the CEOs of identified regional food industry players. 
Table 2: Characteristics of sample food manufacturers

\begin{tabular}{|c|c|c|c|c|c|}
\hline Company & $\begin{array}{l}\text { Interviewee/ } \\
\text { Respondent }\end{array}$ & $\begin{array}{l}\text { Legal status of } \\
\text { company }\end{array}$ & $\begin{array}{c}\text { No. of } \\
\text { employees }\end{array}$ & $\begin{array}{l}\text { Annual } \\
\text { turnover } \\
\text { (RM) }\end{array}$ & Business \\
\hline Company 1 & $\begin{array}{c}\text { CEO (Ex-president } \\
\text { of the Batu Pahat } \\
\text { Chinese Chamber of } \\
\text { Commerce) }\end{array}$ & $\begin{array}{l}\text { Private limited } \\
\text { liability }\end{array}$ & 300 & $\begin{array}{l}20 \text { million to } \\
50 \text { million }\end{array}$ & $\begin{array}{c}\text { Snacks food } \\
\text { manufacture } \\
\text { r with three } \\
\text { subsidiaries }\end{array}$ \\
\hline Company 2 & $\begin{array}{l}\text { CEO (Community } \\
\text { leader of Chinese } \\
\text { Chamber of } \\
\text { Commerce) }\end{array}$ & $\begin{array}{l}\text { Private limited } \\
\text { liability }\end{array}$ & 50 & $\begin{array}{l}10 \text { million to } \\
20 \text { million }\end{array}$ & $\begin{array}{c}\text { Food } \\
\text { manufacture } \\
\mathrm{r} \text { - bottling } \\
\text { and canning } \\
\text { of various } \\
\text { fruit } \\
\text { products }\end{array}$ \\
\hline Company 3 & $\begin{array}{c}\text { CEO (Local } \\
\text { community head) }\end{array}$ & $\begin{array}{l}\text { Private limited } \\
\text { liability }\end{array}$ & 7 & $\begin{array}{l}1 \text { million to } \\
10 \text { million }\end{array}$ & $\begin{array}{c}\text { Chips } \\
\text { manufacture } \\
\text { r }\end{array}$ \\
\hline Company 4 & CEO & $\begin{array}{c}\text { Sole } \\
\text { proprietorship }\end{array}$ & 10 & $\begin{array}{l}\text { Less than } 1 \\
\text { million }\end{array}$ & $\begin{array}{c}\text { Dumpling } \\
\text { manufacture } \\
\mathrm{r}\end{array}$ \\
\hline Company 5 & CEO & $\begin{array}{c}\text { Sole } \\
\text { proprietorship }\end{array}$ & 7 & $\begin{array}{l}\text { Less than } 1 \\
\text { million }\end{array}$ & $\begin{array}{c}\text { Food } \\
\text { manufacture } \\
r\end{array}$ \\
\hline
\end{tabular}

\section{Categories of Drivers}

Table 3 tabulates the categories of drivers obtained from the interviews. Data reduction and data display were applied to get the inference of the interviews' contents. Table 4 tabulates the distribution of the drivers based on the degree of impact and Table 5 tabulates the distribution of the dirvers based on the degree of uncertainty.

Table 3: Categories of drivers obtained from the interviews

\begin{tabular}{|c|l|l|}
\hline No. & \multicolumn{1}{|c|}{$\begin{array}{c}\text { Categories of } \\
\text { Drivers }\end{array}$} & \multicolumn{1}{c|}{ Key Drivers } \\
\hline 1 & Social & $\begin{array}{l}\text { Consumer oriented development, efficiency of university } \\
\text { management }\end{array}$ \\
\hline 2 & Technological & $\begin{array}{l}\text { R\&D, solving technical issues, new product line, technology } \\
\text { transfer }\end{array}$ \\
\hline 3 & Environmental & - \\
\hline 4 & Economic & Market condition, economic of scales, competitive advantage \\
\hline
\end{tabular}

Ng Kim-Soon, Juwita Anwar, Wahid Razzaly and Abd Rahman Ahmad (2015), Journal of Southeast Asian Research, DOI: 10.5171/2015. 725644 


\begin{tabular}{|c|l|l|}
\hline 5 & Political & Government policies \\
\hline 6 & Value & Trust and confidence \\
\hline
\end{tabular}

Table 4: Distribution of the drivers based on the degree of impact

\begin{tabular}{|c|c|c|c|c|c|c|c|c|}
\hline & Key Drivers & C1 & $\mathrm{C} 2$ & C3 & $\mathrm{C4}$ & C5 & $\begin{array}{l}\text { Number } \\
\text { of YES }\end{array}$ & $\begin{array}{c}\text { Degre } \\
\text { e of } \\
\text { impac } \\
t\end{array}$ \\
\hline Driver 1 & $\mathrm{R} \& \mathrm{D}$ & YES & YES & YES & YES & YES & 5 & 3 \\
\hline Driver 2 & $\begin{array}{l}\text { Rate of technology } \\
\text { adoption }\end{array}$ & YES & YES & YES & NO & YES & 4 & 3 \\
\hline Driver 3 & Government policies & YES & YES & YES & NO & YES & 4 & 3 \\
\hline Driver 4 & Trust and confidence & YES & YES & NO & NO & YES & 3 & 2 \\
\hline Driver 5 & $\begin{array}{l}\text { Consumer oriented } \\
\text { development }\end{array}$ & YES & NO & NO & NO & YES & 2 & 1 \\
\hline Driver 6 & $\begin{array}{l}\text { Efficiency of university } \\
\text { management }\end{array}$ & NO & NO & NO & YES & YES & 2 & 1 \\
\hline Driver 7 & Competitive advantage & YES & NO & YES & NO & NO & 2 & 1 \\
\hline Driver 8 & Solving technical issues & YES & YES & NO & NO & NO & 2 & 1 \\
\hline Driver 9 & Accessing funds & YES & YES & NO & NO & NO & 2 & 1 \\
\hline $\begin{array}{c}\text { Driver } \\
10\end{array}$ & New product line & YES & NO & NO & NO & NO & 1 & 0 \\
\hline $\begin{array}{c}\text { Driver } \\
11 \\
\end{array}$ & Market condition & NO & NO & NO & NO & YES & 1 & 0 \\
\hline $\begin{array}{c}\text { Driver } \\
12\end{array}$ & Economic of scales & NO & YES & NO & NO & NO & 1 & 0 \\
\hline
\end{tabular}

Note: C1-Company 1, C2-Company 2, C3-Company 3, C4-Company 4 and C5-Company 5

\begin{tabular}{|c|c|c|c|c|}
\hline Number of YES & $\geq 4$ & 3 & 2 & $\leq 1$ \\
\hline Degree of impact & 3 & 2 & 1 & 0 \\
\hline
\end{tabular}

Table 5: Distribution of the drivers based on the degree of uncertainty

\begin{tabular}{|l|l|c|c|c|c|c|c|c|c|}
\hline & \multicolumn{1}{|c|}{ Key Drivers } & C1 & C2 & C3 & C4 & C5 & $\begin{array}{c}\text { Average } \\
\text { Ranking }\end{array}$ & Rank & $\begin{array}{c}\text { Degree of } \\
\text { uncertainty }\end{array}$ \\
\hline Driver 1 & R\&D & 12 & 1 & 12 & 7 & 8 & 8.0 & 9 & 1 \\
\hline Driver 2 & $\begin{array}{l}\text { Rate of tehcnology } \\
\text { adoption }\end{array}$ & 4 & 2 & 3 & 3 & 4 & 3.2 & 2 & 3 \\
\hline Driver 3 & Government policies & 2 & 3 & 1 & 5 & 1 & 2.4 & 1 & 3 \\
\hline Driver 4 & Trust and confidence & 11 & 10 & 7 & 8 & 2 & 7.6 & 8 & 1 \\
\hline
\end{tabular}

Ng Kim-Soon, Juwita Anwar, Wahid Razzaly and Abd Rahman Ahmad (2015), Journal of Southeast Asian Research, DOI: 10.5171/2015. 725644 


\begin{tabular}{|l|l|l|l|l|l|l|l|l|l|}
\hline Driver 5 & $\begin{array}{l}\text { Consumer oriented } \\
\text { development }\end{array}$ & 1 & 6 & 6 & 4 & 9 & 5.2 & 4 & 2 \\
\hline Driver 6 & $\begin{array}{l}\text { Efficiency of university } \\
\text { management }\end{array}$ & 8 & 4 & 8 & 10 & 3 & 6.6 & 5 & 2 \\
\hline Driver 7 & Competitive advantage & 5 & 8 & 2 & 2 & 6 & 4.6 & 3 & 3 \\
\hline Driver 8 & Solving technical issues & 6 & 7 & 9 & 1 & 11 & 6.8 & 6 & 2 \\
\hline $\begin{array}{c}\text { Driver 9 } \\
\text { Accessing funds }\end{array}$ & 10 & 5 & 4 & 12 & 5 & 7.2 & 7 & 1 \\
\hline $\begin{array}{c}\text { Driver } \\
\mathbf{1 0}\end{array}$ & New product line & 3 & 11 & 10 & 9 & 12 & 9.0 & 11 & 0 \\
\hline $\begin{array}{c}\text { Driver } \\
\mathbf{1 1}\end{array}$ & Market condition & 9 & 9 & 5 & 11 & 7 & 8.2 & 10 & 0 \\
\hline $\begin{array}{c}\text { Driver } \\
\mathbf{1 2}\end{array}$ & Economic of scales & 7 & 12 & 11 & 6 & 10 & 9.2 & 12 & 0 \\
\hline
\end{tabular}

Note: C1-Company 1, C2-Company 2, C3-Company 3, C4-Company 4 and C5-Company 5

\begin{tabular}{|c|c|c|c|c|}
\hline Ranking & $1-3$ & $4-6$ & $7-9$ & $10-12$ \\
\hline Degree of uncertainty & 3 & 2 & 1 & 0 \\
\hline
\end{tabular}

\section{Impact-uncertainty Analysis}

Basing on the drivers derived in the Table 4 and Table 5, an impact-uncertainty analysis was figured out as shown in Figure 1. The list of key drivers coded in the figure is shown in Table 6.
At this stage, the most uncertain and the most impactful drivers were identified. There are two key drivers as shown in the figure derived from analysis of the primary data collected. In this case, the rate of technology adoption and government policies are the key drivers which will shape the future of UIC between UTHM and the food manufacturers of Batu Pahat. These are D2 and D3 as highlighted in Table 6. 


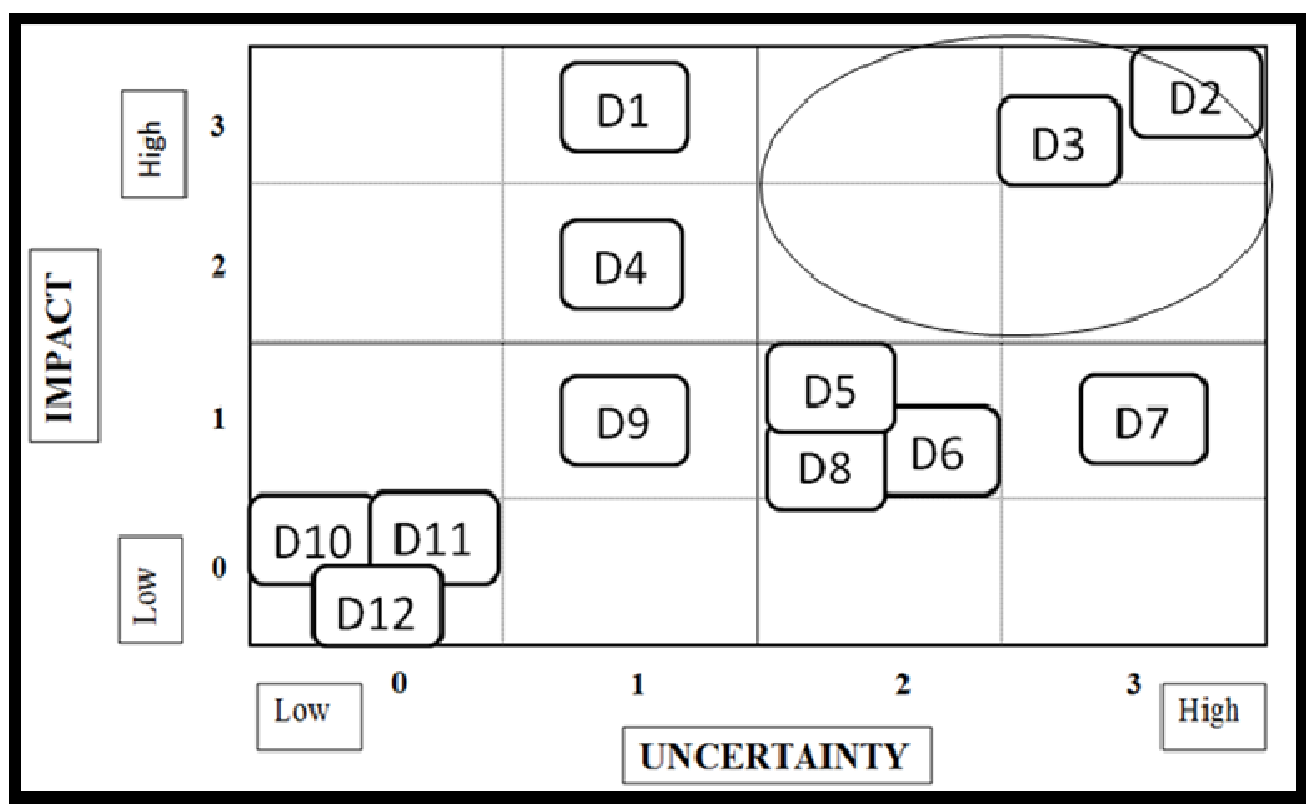

Figure 1: Impact-uncertainty analysis (Code of driver is listed in Table 6)

Figure 1

Table 6: Key drivers

\begin{tabular}{|c|l|}
\hline Code & \multicolumn{1}{|c|}{ Drivers } \\
\hline D1 & R\&D \\
\hline D2 & Rate of technology adoption \\
\hline D3 & Government policies \\
\hline D4 & Mutual trust and confidence \\
\hline D5 & Consumer oriented development \\
\hline D6 & Efficiency of university management \\
\hline D7 & Competitive advantage \\
\hline D8 & Solving technical issues \\
\hline D9 & Accessing funds \\
\hline D10 & New product line \\
\hline D11 & Market condition \\
\hline D12 & Economic of scales \\
\hline
\end{tabular}

\section{Discussion}

Malairaja and Zawdie (2008) reviewed that companies collaborate with university are usually more productive and more competitive in their market share, quality of products and services and cost. This is reflected by many higher education institutions and governments in the world in reforming their educational and policies or strategies to foster and commercialize their innovation to reap the benefits of university and industry collaboration for economic and social gains (Harman, 2005). 
The expectation of a university with society has changed in recent times. University is transforming from what has been perceived as an ivory towers in the past (Wells et al., 2009 ) to that as a catalytic agent of change to propel the need to compete in the global economy. In Malaysia, the Ministry of Education has assumed its leadership role. Under its Critical Agenda Project, it has kicked starts the UIC intervention through the launched of "Launching of Plans to Strengthen University-Industry Cooperation and Cluster Programme" in July 2010. Karatzoglou (2012) and Dlouha et al., (2012) reported that as leadership role in UIC intervention, it creates sustainable change within the modern society. This new role of university serves to bridge the gap between government, society and all potential stakeholders by fostering closer collaborative works (Keen et al., 2005). The Malaysian Ministry university-industry intervention is strategically aimed at improving academiaindustry relationship through activities like intensifying strengthening applied and developmental research; expand funding opportunities to the industry and the general public, enhancing collaboration with the industry in business activities. This has led to the establishment of University-Industry Collaborations Department at UTHM. The key objectives of this Department includes creating strategic linkages with industry, support and enhancing learning experience and industrial training, bridging the gap between the academia and industry, and to support staff attachment programmes in the industry.

The formal establishment of UIC of UTHM with the industry is very recent. Hence, it is timely to carry out this research work to determine the key drivers of success of UIC between UTHM and the food processing industry in Batu Pahat, a town located in the state of Johor, Malaysia. This is achieved through a qualitative research approach. It is found that the key drivers of change in UIC between UTHM and the food processing industry in Batu Pahat are rate of technology adoption and government policies. Table 7 tabulates the uncertainty axis analysis. There are two possibilities of outcomes for each key driver is shown in Table 7.

Table 7: Uncertainty axis analysis

\begin{tabular}{|c|l|c|c|}
\hline \multirow{2}{*}{ No. } & \multirow{2}{*}{ Key Drivers } & Positive (+) & Nwo possibilities \\
\cline { 3 - 4 } & & Innovator & Laggard \\
\hline $\mathbf{1}$ & $\begin{array}{l}\text { Rate of technology } \\
\text { adoption }\end{array}$ & $\begin{array}{c}\text { Encouraging / supportive } \\
\text { government policies }\end{array}$ & $\begin{array}{c}\text { Discouraging / unsupportive } \\
\text { government policies }\end{array}$ \\
\hline $\mathbf{2}$ & Government policies & & \\
\hline
\end{tabular}

First driver of change is rate of technology adoption by the technology users is a key driver of change that drives the future of UIC. This results support the prior research of Cohen (2004), who stated that technology is the driver of new alliances among academia, business and government.
Government policies are encompassing the interaction between university and industry. Mpehongwa (2013) reviewed that there is no single systematic process model of depicting the manner academia-industry-government is organized. There are three theoretical models academia-industry-government collaborative linkages (Ssebuwufu et al., 2012). Goransson and Brundenius (2011) 
described the National Systems of Innovation (NIS) model views innovation as a collective process where firms innovate in isolation within a larger system involving firms, universities, research centers, government agencies and other actors. Edquist (2004) explained that this model considers all aspects of the country economic and institutional structure that influence the development, diffusion and use of innovation. Next is the Triple Helix Model developed by Etzkowtitz and Leydesdorff in 1997 (Etzkowitz \& Leydesdorff, 2000). It describes that innovation is achieved by alliance of university and industry with the support of government policies. Etzkowtitz (2008)

\section{Recommendation}

More studies on how to reduce the gap between academicians (university) and the industry is needed as it is a main barrier for successful UIC. Another suggestion is to find out a suitable model of collaboration which can be used by UTHM and the food processing industry in Batu Pahat. There is much to learn from bringing together key experts, experienced leaders, and the players together in highlighting, disseminating and sharing knowledge on issues which will be significant in building links and bridges the gaps between universities and private industries to work towards a successful, winwin knowledge and economic benefits partnership. Sharing of ideas, practices, and to connect between the different sectors leads to building a thriving model for regional university industry collaboration (Kim-Soon et al., 2014).

A model can help both parties to increase the chances of success of UIC. Reyhani and Mazzarol (2012) proposed government and other relevant institutions can focus on strategies adoption at macro level and the academics, industrial practitioners to work together at the micro level in a conducive business environment for economic growth. As described earlier, Ssebuwufu et al., (2012) state that there are three theoretical models academia-industry-government described academia as focus on establishing institutional interface structures including industry liaison / technology transfer offices, business and technology incubators, and fostering entrepreneurialism through various policies and incentives. In Mode II Knowledge Production, innovation is viewed as context driven, problem-focused and interdisciplinary. Knowledge is produced in the context of application, quality control, social accountability reflexivity, and heterogeneity organizational diversity (Goransson \& Brundenius, 2011). Triple Helix III Relations was developed by Etzkowitz and Leydesdorff (2000).

collaboration. However, there are also approaches that top-down, bottom-up or mixed mode. Thus, depending on government initiative, governance modes of university, incentive systems e.g. related to university ownership of intellectual property, market competitive and other environment factors, a relevant and efficient model will serve well for UIC success.

\section{Conclusion}

This study found that the rate of technology adoption and government policies are the two key drivers of change in UIC between UTHM and the food processing industry in Batu Pahat. The future of UIC is shaped by the government initiative in policy making and also the rate of technology adoption of UTHM and the food processing industry in Batu Pahat. However, depending on government initiative, governance modes of university, incentive systems e.g. related to university ownership of intellectual property, market competitive and other environment factors, a relevant and efficient model will serve well for UIC success.

\section{Acknowledgements}

This research project is supported by Universiti Tun Hussein Onn Malaysia through 
its Grant Number C043 to Dr. Ng Kim-Soon. This work is also done in collaboration with MIGHT on the use of STEEPV, impact / uncertainty analaysis methodology propagated by MIGHT. The authors wish to thank the respondents who were interviewed and their willingness of sharing their experiences, time and patience for participating in this project.

\section{Glossary of abbreviations}

CEOs - Chief Executive Officers

R\&D - Research and Development

STEEPV - An analysis which stands for Social, Technological, Economic, Environmental, Political and Values

UIC - University-Industry Collaborations UTHM - Universiti Tun Hussein Onn Malaysia (A Public University located in Batu Pahat Township)

\section{References}

1. Agriculture and Agri-Food Canada. (2010). Consumer Trend Report- Convenience. Canada: Her Majesty the Queen in Right of Canada.

2. Agrawal, A. and Cockburn, I. (2003). The anchor tenant hypothesis: exploring the role of large, local, R\&D intensive firms in regional innovation systems, International Journal of Industrial Organization, Vol. 21(9), 1227-1253.

3. Arora, S., and Cason, T. (1996). Why do Firms Volunteer to Exceed Environmental Regulations? Understanding Participation in EPA's 33/50 Program. Land Economics, 72(4), 413-432.

4. Baysal, O. O. (2007). Strategies for an Effective University-Industry Collaboration in Industrial Design Education: A Case Study of Graduation Projects.

5. Bjerregaard, T. (2009). Universitiesindustry collaboration strategies: a micro- level perspective. European Journal of Innovation Management, 12(2), 161-176.

6. Bolton, K. R. (2011). Religion Globalization: The Trans-Pacific Partnership. Foreign Policy Journal.

7. Business and Professional Women's Foundation. (2011). Gen Y Women in the Workplace: Focus Group Summary Report. Virginia Allan Fund.

8. Cohen, G. (2004). Technology Transfer: Strategic Management in Developing Countries. New Delhi: Sage Publications India Pvt Ltd.

9. Czarnitzki, D., Hussinger, K., and Schneider, C. (2011). R\&D Collaboration with Uncertain Intellectual Property Rights. Pacific Rim Innovation Conference . Melbourne: Katholieke Universiteit.

10.Dasher, R. B. (2004). Implementing new patterns of University-Industry Collaboration in Japan: Lessons from the U. S., STARC Symposium.

11.Dlouha, J., Machackova-Henderson, L. and Dlouhy, J. (2012), Learning networks with involvement of higher education institutions, Journal of Cleaner Production, Vol. 49, 95-104.

12.Dodd, S.D. and Patra, E. (2002), National differences in entrepreneurial networking, Entrepreneurship \& Regional Development, Vol. 14(2), 117-134.

13.Edquist, C. (2004). Systems of Innovation: Perspectives and Challenges. In: Fagerberg J, Mowery D, Nelson R (Eds.). The Oxford Handbook of Innovation. Oxford University Press, Oxford pp.181-208.

14.Esham, M. (2008). Strategies to Develop University-Industry Linkages in Sri Lanka. National Education Commision Sri Lanka Study Series No. 4. 
15.Etzkowtitz, H. (2008). The Triple Helix: University-Industry-Government Innovation in Strengthening University-Industry Linkages in Africa: A Study of Institutional Capacities and Gaps Action. Routledge, New York.

16. Etzkowitz, H., and Leydesdorff, L. (2000). The Dynamics of Innovation: from National Systems and "Mode 2" to a Triple Helix of University-Industry-Government Relations. Research Policy 29, 109-123.

17.Fassin, Y. (2000). The Strategic Role of University-Industry Liaison Offices. The Journal of Research Administration, 1(2).

18. Foryszewski, S. (2010). The Power of Partnerships. UK, Outsource Magazine.

19.Gertner, D., Roberts, J., and Charles, D. (2011). University-industry Collaboration: A CoPs Approach to KTPs. Journal of Knowledge Management, 15(4), 625-647. doi:10.1108/13673271111151992

20.Goransson B, and Brundenious, C. (2011). Universities in Transition: The Changing Role and Challenges for Academic Institutions. Springer, New York.

21.Hamidah, H., Maziah, M., Ayesha, B., Subahan, T., and Rahayah, A. S. (2012). The Development of a Malaysian Model Internship Programme (MyMIP): A Preceptor Model for Nurses in Their Early Stage of Profession. Procedia - Social and Behavioral Sciences, 64(1999), 492-500. doi:10.1016/j.sbspro.2012.11.058

22.Harman, G. (2005). Political instruments employed by governments to enhance university research and knowledge transfer capacity, Higher Education Management and Policy, 17(2), 75-89.

23.Hermans, J., and Castiaux, A. (2007). Knowledge Creation Through Universityindustry Collaborative Research Projects. The Electronic Journal of Knowledge Management,
5(1), 43-54. Retrieved from http://www.ejkm.com

24.Holland, L. (2011). Outsourcing to Cut Costs- Ten Top Tips for SMEs. UK: Outsource Magazine.

25.Inkpen, A. C., and Curall, S. C. (2004). The Coevolution of Trust, Control and Learning in Joint Ventures, pp. 44-56.

26.Ismail, N., and Abas, Z. (Eds.). (2010). Strategic Enhancement Plan for UniversityIndustry (pp. 1-27). Industry Relations Division, Department of Higher Education, Ministry of Higher Education Malaysia.

27.Junaini, S. N., Fadzir, S. F. S., Sidi, J., Khiri, M. J. A. and Othman, R. M. (2008). Harnessing University-Industry Collaboration in Malaysia through Industrial Training. 2008 3rd International Conference on Information and Communication Technologies: From Theory to Applications, 1-5. doi:10.1109/ICTTA.2008.4530132

28.Kang, N., and Sakai, K. (2000). International Strategic Alliances: Their Role in Industrial Globalisation. OECD Science, Technology and Industry Working Papers.

29.Karatzoglou, B. (2012). An in-depth literature review of the evolving roles and contributions of universities to education for sustainable development, Journal of Cleaner Production, Vol. 49, 44-53.

30.Kim-Soon, N., Nikol, I.A., Razzaly, W. and Ahmad, A.R. (2014). A Preliminary Examination of Stimulating and Building University-Industry Collaborative Works at a Public University, IEEE International Conference on Management of Innovation \& Technology, Singapore, The Institute of Electrical and Electronics Engineers, Incorporated.

31.King, A., and Lenox, M. (2000). Industry Self-regulation without Sanctions: the Chemical Industry's Responsible Care 
Program. Academy of Management Journal, 43(4), 698-716.

32.Kondo, M. (2011). University-industry Collaboration in Japan by Technology Fields. Journal of Knowledge-based Innovation in China, 3(1), 15-28. doi:10.1108/17561411111120846

33.Larson, A. (1992). Entrepreneurial Network Development: Trusting in the Process (Vol. 61, 76-104). doi:10.1016/j.jbusres.2007.06.018

34.Laursen, K., Reichstein, T. and Salter, A. (2011). Exploring the effect of geographical proximity and university quality on university-industry collaboration in the United Kingdom, Regional Studies, Vol. 45(4), 507-523.

35. Malairaja, C. and Zawdie, G. (2008). Science parks and university-industry collaboration in Malaysia, Technology Analysis \& Strategic Management, 20:6, 727739, DOI: $10.1080 / 09537320802426432$

36. Marshall, S., Bowe, J. A. and Schroder, M. J. (2007). Consumer Understanding of UK Salt Intake Advice. British Food Journal, 109(3), 233-245.

37. Miles, M. B. and Huberman, A. M. (1994). Qualitative Data Analysis: An Expanded Sourcebook. Sage Publictions Incorporated.

38. Mowery, D. C., Oxley, J. E. and Silverman, B. S. (1996). Strategic Alliances and Interfirm Knowledge Transfer. Strategic Management Journal, 17, 77-91.

39. Mpehongwa, G. (2013). Academiaindustry-government linkages in Tanzania: trends, challenges and prospects, Educational Research and Reviews, Vol. 8(21), 2093-2100, DOI: $10.5897 / E R R 2013.1562$

40.Othman, N. (2011). An Assessment of a University-industry Partnership in a
Malaysian University. International Journal of Business and Social Science, 2(8), 94-103.

41.Pallot, M. (2009). ECOSPACE Survey on Barriers Affecting Collaboration Effectiveness and Efficiency. ECOSPACE Consortium.

42.Pecas, P. and Henriques, E. (2006). Best practices of Collaboration between University and Industrial SMEs. Benchmarking: An International Journal, 13(1/2), 54-67. doi:10.1108/14635770610644574

43.Pillkahn, U. (2008). Using Trends and Scenarios as Tools for Strategy Development. Erlangen: Publicis Corporate Publishing.

44.Piva, E. and Rossi-Lamastra, C. (2013). Systems of Indicators to Evaluate the Performance of University-Industry Alliances: A Review of the Literature and Directions for Future Research, Measuring Business Excellence, Vol. 17(3), 40-54.

45.Reyhani, M. and Mazzarol, T. (2012). Nurture or nature: interplay between the individual and the institution within the commercialisation practices of Australian Universities, ACERE-Diana Conference, 31 January to 3 February 2012, Fremantle Western Australia.

46.Shariff, M. (2010). Technology Transfer in a Malaysian University: UPM's Experience. Kuala Lumpur, Wilayah Persekutuan, Malaysia. Retrieved from UPM.

47.Sohail, M. A. (2009). Knowledge sharing in higher educaiton institutions Perspective from Malaysia. The Journal of information and knowledge management systems, 125-142.

48.Ssebuwufu, J., Ludwick, T. and Béland, M. (2012). Strengthening University-Industry Linkages in Africa: A Study of Institutional Capacities and Gaps, Association of African Universities (AAU), 11, Aviation Road Extension, P.O. Box 5744, Accra-North Ghana

Ng Kim-Soon, Juwita Anwar, Wahid Razzaly and Abd Rahman Ahmad (2015), Journal of Southeast Asian Research, DOI: 10.5171/2015. 725644 
49.Vauterin, J. J. (2012). Value Creation in International Higher Education: The Role of Boundary Spanning in University-industry Collaboration. International Journal of Quality and Service Sciences, 4(3), 283-298. doi:10.1108/17566691211269594

50.Vlaar, P. W. L., Van Den Bosch, F. A. and Volberda, H. W. (2007). On the Evolution of Trust, Distrust and Formal Coordination and
Control in Interorganizational Relationships. Toward an Integrative Framework. Group and Organization Management, 32(4).

51.Wells, P., Bristow, G., Nieuwenhuis, P. and Christensen, T.B. (2009). The role of academia in regional sustainability initiative: Wales, Journal of Cleaner Production, Vol. 17, 1116-1122. 